\title{
Study on Chemical Removal of Nitric Oxide (NO) as a Main Cause of Fine Dust (Air Pollution) and Acid Rain
}

\author{
Hyeon Jin Seo ${ }^{\mathrm{a}}$, Rak Hyun Jeong ${ }^{\mathrm{b}}$, Jang-Heon Boo ${ }^{\mathrm{c}}$, Jimin Song ${ }^{\mathrm{c}}$, and Jin-Hyo Boo ${ }^{\mathrm{a}, \mathrm{b} *}$ \\ ${ }^{a}$ Department of Chemistry, Sungkyunkwan University, Suwon 16419, Korea \\ ${ }^{b}$ Institute of Basic Science, Sungkyunkwan University, Suwon 16419, Korea \\ ${ }^{c}$ Songnae High School, Bucheon 14741, Korea
}

Received September 20, 2017; revised October 18, 2017; accepted November 21, 2017

\begin{abstract}
This study was conducted to remove $\mathrm{NO}_{\mathrm{x}}$, which is the main cause of fine dust and air pollution as well as acid rain. $\mathrm{NO}_{\mathrm{x}}$ was tested using 3\% $\mathrm{NO}$ (diluted in $\mathrm{He}$ ) as a simulated gas. Experiments were sequentially carried out by oxidizing $\mathrm{NO}$ to $\mathrm{NO}_{2}$ and absorbing $\mathrm{NO}_{2}$. Especially, we focused on the changes of $\mathrm{NO}$ oxidation according to both oxidant $\left(\mathrm{NaClO}_{2}\right)$ concentration change $(1 \sim 10 \mathrm{M})$ and oxidant $\mathrm{pH}$ change $(\mathrm{pH}=1 \sim 5)$ by adding $\mathrm{HCl}$. In addition, we tried to suggest a method to improve $\mathrm{NO}_{2}$ absorption by conducting $\mathrm{NO}_{2}$ reduction reaction with reducing agent $(\mathrm{NaOH})$ concentration $(40 \sim 60 \%)$. It was found that $\mathrm{NO}$ removal efficiency increased as both concentration of oxidant and flow rate of $\mathrm{NO}$ gas increased, and $\mathrm{NO}$ decreased more effectively as the $\mathrm{pH}$ of hydrochloric acid added to the oxidant was lower. The $\mathrm{NO}_{2}$ adsorption was also better with increasing $\mathrm{NaOH}$ concentration, but the $\mathrm{NO}$ removal efficiency was $\sim 20 \%$ lower than that of the selective NO reduction. Indeed, this experimental method is expected to be a new method that can be applied to the capture and removal of fine dust caused by air pollution because it is a method that can easily remove NO gas by a simple device without expensive giant equipment.
\end{abstract}

Keywords: $\mathrm{NO}$ oxidation, $\mathrm{NO}_{2}$ absorption, Fine dust, Air pollution, Acid rain

\section{Introduction}

Fine dust that is striking our country every spring is often from China, but most of them come from cars using diesel engines [1]. If we do not solve this problem, Korea's fine dust problem will not be solved forever. However, people have not found a solution to the problem other than reducing diesel-powered vehicles, and many still do not see the problem of solving the fine dust problem. Particulate Matter (PM) or dust is an air pollutant containing a large number of air pollutants together with sulfur dioxide, nitrogen oxides, lead, ozone, carbon monoxide, etc. It occurs in automobiles, factories, etc., and it is referred to as "PM10". When the particle is $2.5 \mu \mathrm{m}$ or less, it is referred to as " $\mathrm{PM}_{2.5}$ " and called as "ultrafine dust" [1]. Air pollutants from fossil fuels such as petroleum and coal or from exhaust fumes from automobile soot are known to be the main cause of fine dusts, but methods for completely removing ultrafine dusts have not been developed yet [1,2].

In addition, recently, regulations for pollutant emission at sea have been strengthened, and accordingly, there is a growing interest in pollutant control technology $[3,4]$. Acid rain is defined as the accumulation of atmospheric acidic

*Corresponding author

E-mail: jhboo@skku.edu substances in wet or dry conditions in the ecosystem. Acid rain refers to the ratio of chemicals in the air that combine with the rain to become acidified $[1,3]$. When the natural rain is in equilibrium with carbon dioxide in the atmosphere, the $\mathrm{pH}$ is lower than 5.6. Today, much more acidic rainfall is being observed all over the world. Acid rain is mainly caused by human release of sulfur and nitrogen mixtures that produce acidic reactivity in the atmosphere [5]. Sulfur dioxide and nitric oxide are air pollutants, which combine with the water vapor of the atmosphere to form acidic substances and acid rain. The acidic material is moved by the wind and becomes acid rain. The acid rain falls to a distance of about $4,023 \mathrm{~km}$ from where the pollutants are generated [6]. Acid rain made by humans damages lakes, forests, wildlife, and acidifies lakes to kill fish and other aquatic life. As the producer of the food chain is destroyed, the number of birds is reduced. It is because birds' food, insects, plants and aquatic life are killed by acid rain [7]. Not all areas where acid rain comes down have the same results. That is, the potential of the area capable of neutralizing acidic substances determines the amount of damage. Alkaline soil neutralizes acid. Therefore, areas with high alkaline soil are less damaging than those with neutral or acid soil. Several temporary measures have been taken to solve the acid rain problem, such as attempting to neutralize the acid by 
adding lime to the contaminated lake, but they have not had much effect. The solution to the acid rain problem is to remove pollutants that cause acid rain. We must reduce the use of fossil fuels such as coal, especially those containing a lot of sulfur. In order to protect forests, it is necessary to reduce the amount of automobile exhaust gas, use alternative energy, and use a lot of public transportation. This process can solve the acid rain problem [8].

The International Maritime Organization (IMO), under the United Nations (UN), announced that from 2016, the emission regulation at sea would be strengthened from the current Tier II to Tier III [9]. Accordingly, research and development on the removal of sulfur oxides $\left(\mathrm{SO}_{\mathrm{x}}\right)$ and nitrogen oxides $\left(\mathrm{NO}_{\mathrm{x}}\right)$ contained in gas discharged from vessels have been actively carried out, but there are still many problems to be solved. In addition, various researches to prevent the acidification of the soil due to acid rain and to create a more pleasant and affluent life (well-being culture) by decreasing the atmospheric concentration of sulfur oxides $\left(\mathrm{SO}_{\mathrm{x}}\right)$ and nitrogen oxides $\left(\mathrm{NO}_{\mathrm{x}}\right)$ [10]. Therefore, through this study, we tried to suggest a new method to solve the ultrafine dust problem and contribute to solving the acid rain problem. Especially, for smooth $\mathrm{NO}_{\mathrm{x}}$ treatment, (1) first remove $\mathrm{NO}$ by oxidizing it to $\mathrm{NO}_{2}$, and (2) finally remove $\mathrm{NO}_{2}$ by absorption reaction using sodium hydroxide solution, which dissolves in alkaline solution, were suggested in this study

\section{Experimental Background and Procedure}

\section{1. $\mathrm{NO}_{\mathrm{x}}$ generation and reduction principle}

It is known that various compounds exist in the nitrogen oxides depending on the bonding state of nitrogen and oxygen. Most of what is generated by combustion of fuel is $\mathrm{NO}$ and $\mathrm{NO}_{2}$, and is generally referred to as $\mathrm{NO}_{\mathrm{x}}$ (hereinafter referred to as $\mathrm{NO}_{\mathrm{x}}$ ). The ratio of $\mathrm{NO} / \mathrm{NO}_{\mathrm{x}}$ in the combustion gas discharged from the diesel engine combustion equipment is about 90 to $95 \%$, and the $\mathrm{NO}_{\mathrm{x}}$ in the exhaust gas is mostly NO [11]. NO is a colorless, odorless gas and hardly soluble in water. $\mathrm{NO}_{2}$ is produced by oxidation of $\mathrm{NO}$ in the atmosphere, and it is converted to nitric acid $\left(\mathrm{HNO}_{3}\right)$ by binding with moisture, which is a main cause of acid rain. $\mathrm{NO}_{\mathrm{x}}$ can be odorous even in the presence of 1 to $3 \mathrm{ppm}$, and it inhibits oxygen delivery by diminished immune responses by respiratory diseases and methemoglobin formation by reaction with blood hemoglobin. $\mathrm{NO}_{2}$ is more soluble than $\mathrm{NO}$, and when it is high, it is a reddish-brown irritant gas, which is five times more toxic than NO. Acute damage causes eye, nasal irritation and pulmonary hyperemia, pulmonary edema, obstructive bronchitis and pneumonia.

$\mathrm{NO}_{\mathrm{x}}$ generated in the combustion process of the fuel is generated by the following two routes.

(1) Thermal $\mathrm{NO}_{\mathrm{x}}$ : Nitrogen and oxygen in combustion air react at high temperature to become $\mathrm{NO}_{\mathrm{x}}$. In this case, the higher the combustion temperature, the higher the $\mathrm{O}_{2}$ in the combustibility, and the longer the residence time of the combustion gas in the higher temperature region, the more $\mathrm{NO}_{\mathrm{x}}$ is generated [12].

(2) Fuel $\mathrm{NO}_{\mathrm{x}}$ : When a portion of the nitrogen oxides contained in the fuel burns, it is oxidized to become $\mathrm{NO}_{\mathrm{x}}$, and there is almost no nitrogen $(\mathrm{N})$ compound in the gaseous fuel $[11,13]$.

Therefore, the following basic principle is applied to suppress the generation of $\mathrm{NO}_{\mathrm{x}}$.

(1) Lower the oxygen concentration in the combustion zone.

(2) Shorten the residence time of the combustion gas in the high temperature region.

(3) Lower combustion temperature. Especially, local high temperature area should not be generated.

(4) Using fuel containing less nitrogen

\section{Traditional processes of $\mathrm{NO}_{\mathrm{x}}$ reduction}

The most commonly used methods for treating nitrogen oxides are Selective Non-Catalytic Reduction (SNCR) and Selective Catalytic Reduction (SCR).

(1) Selective non-catalytic reduction (SNCR) [14-16]

The selective non-catalytic reduction method is a method in which a reducing agent containing nitrogen such as ammonia $\left(\mathrm{NH}_{3}\right)$ and urea $\left(\mathrm{NH}_{2} \mathrm{CONH}_{2}\right)$ is injected at a temperature of about 870 to $1150^{\circ} \mathrm{C}$, and the reduced reducing agent is ionized to react with nitrogen oxides. The ammonia and urea are separated according to the temperature range of the point where the reducing agent is injected by the method of decomposing into $\mathrm{N}_{2}, \mathrm{CO}_{2}$ and $\mathrm{H}_{2} \mathrm{O}$. When ammonia is injected, the reaction occurs at a lower temperature than when the urea is injected. Therefore, when the temperature of the injection point is low, ammonia is used. When this method is used, the removal efficiency of nitrogen oxide is about $50 \sim 70 \%$

(2) Selective Catalytic Reduction (SCR) [17,18]

In the selective catalytic reduction method, exhaust gas and a reducing agent are simultaneously brought into contact with a catalyst layer at a temperature of 300 to $400^{\circ} \mathrm{C}$, thereby, reducing $\mathrm{NO}_{\mathrm{x}}$ in exhaust gas to nitrogen $\left(\mathrm{N}_{2}\right)$ and water vapor $\left(\mathrm{H}_{2} \mathrm{O}\right)$ by selective reaction with a reducing agent $\left(\mathrm{NH}_{3}\right)$. The reducing agent used is ammonia water (mainly $25 \%$ ammonia solution), urea (50\% urea solution), etc., injected into the front end of the SCR catalyst and injected into the exhaust gas. The reduction of $\mathrm{NO}_{\mathrm{x}}$ in the SCR reactor is achieved by the following reaction.

$$
\begin{aligned}
& 4 \mathrm{NO}+4 \mathrm{NH}_{3}+\mathrm{O}_{2} \rightarrow 4 \mathrm{~N}_{2}+6 \mathrm{H}_{2} \mathrm{O} \\
& 4 \mathrm{NH}_{3}+6 \mathrm{NO} \rightarrow 5 \mathrm{~N}_{2}+6 \mathrm{H}_{2} \mathrm{O}
\end{aligned}
$$

Since most of the exhaust gas contains $\mathrm{O}_{2}$ component, reaction (1) occurs, so $\mathrm{NO}$ and $\mathrm{NH}_{3}$ react with each other 
at a ratio of $1: 1$, and $\mathrm{NH}_{3}$ is required as much as the $\mathrm{NO}$ reduction amount. In the exhaust gas, about $5 \%$ of the total $\mathrm{NO}_{\mathrm{x}}$ is the $\mathrm{NO}_{2}$ component, and the reaction formula is as follows.

$$
\begin{aligned}
& 2 \mathrm{NO}_{2}+4 \mathrm{NH}_{3}+\mathrm{O}_{2} \rightarrow 3 \mathrm{~N}_{2}+6 \mathrm{H}_{2} \mathrm{O} \\
& 8 \mathrm{NH}_{3}+6 \mathrm{NO}_{2} \rightarrow 7 \mathrm{~N}_{2}+6 \mathrm{H}_{2} \mathrm{O}
\end{aligned}
$$

According to reaction (3), $\mathrm{NH}_{3}$ is required twice as much as $\mathrm{NO}$ for $\mathrm{NO}_{2}$ reduction, but the $\mathrm{NO}_{2}$ content in the exhaust gas is as small as about $5 \%$.

\section{Our suggested processes of $\mathrm{NO}_{\mathrm{x}}$ reduction}

\subsection{NO oxidation}

As mentioned above, the $\mathrm{NO}_{\mathrm{x}}$ in the exhaust gas emitted from the engine is largely divided into nitrogen oxide (NO) and nitrogen dioxide $\left(\mathrm{NO}_{2}\right)$. Of these, $\mathrm{NO}$ emissions account for the majority of $\mathrm{NO}_{\mathrm{x}}$ emissions. Accordingly, for smooth $\mathrm{NO}_{\mathrm{x}}$ treatment, $\mathrm{NO}$ is oxidized to $\mathrm{NO}_{2}$ and removed. The oxidizing agent used here is sodium chlorite $\left(\mathrm{NaClO}_{2}\right)$. The chemical mechanism of the oxidation reaction using $\mathrm{NaClO}_{2}$ is shown in the following reaction (5).

$$
\mathrm{NO}+2 \mathrm{NaClO}_{2} \rightleftarrows \mathrm{NO}_{2}+\mathrm{NaClO}_{3}+\mathrm{NaCl}
$$

The formation of chlorine dioxide $\left(\mathrm{ClO}_{2}\right)$ gas is very important for the reaction of the above reaction formula (5) to be activated. It is known that $\mathrm{NaClO}_{2}$ generates $\mathrm{ClO}_{2}$ gas in the acidic range below $\mathrm{pH} 5$ [19]. In the acidic region of $\mathrm{NaClO}_{2}$, the reaction of producing $\mathrm{ClO}_{2}$ gas is as shown in the following reaction formula (6).

$$
5 \mathrm{NaClO}_{2}+4 \mathrm{HCl} \rightleftarrows 4 \mathrm{ClO}_{2}+5 \mathrm{NaCl}+2 \mathrm{H}_{2}
$$

\section{$3.2 \mathrm{NO}_{2}$ absorption reaction}

The $\mathrm{NO}_{2}$ generated through the oxidation reaction is absorbed into the cleaning liquid to be removed. $\mathrm{NO}_{2}$ is known to dissolve well in alkaline solution [20]. The mechanism of absorption reaction with sodium hydroxide $(\mathrm{NaOH})$, which is a representative alkali solution, is shown in the following reaction formula (7).

$$
\mathrm{NO}+\mathrm{NO}_{2}+2 \mathrm{NaOH} \rightleftarrows 2 \mathrm{NaNO}_{2}+\mathrm{H}_{2} \mathrm{O}
$$

When $\mathrm{NO}$ is oxidized to $\mathrm{NO}_{2}$, a reaction mechanism similar to that of reaction (7) is shown. At this time, nitric acid $\left(\mathrm{HNO}_{3}\right)$ is produced as a reaction product (see reaction 8). Therefore, in this experiment, the exact removal rate of $\mathrm{NO}$ gas was obtained by measuring $\mathrm{pH}$ and volume change of aqueous $\mathrm{NaOH}$ solution and titrating with standard acid solution $(\mathrm{HCl})$ according to the formation of $\mathrm{HNO}_{3}$, resulting in determination of both $\mathrm{HNO}_{3}$ and $\mathrm{NO}_{2}$ concentrations and then obtaining $\mathrm{NO}_{2} / \mathrm{NO}$ conversion ratio. (a)

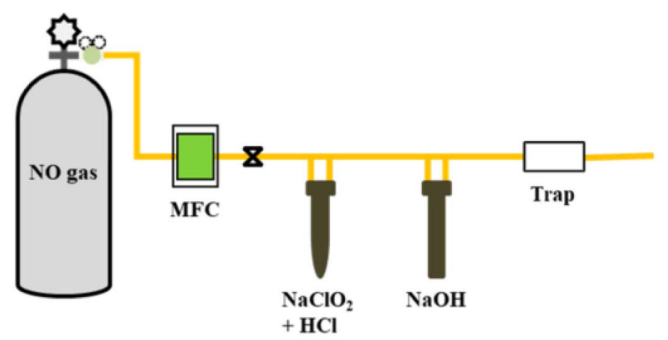

(b)

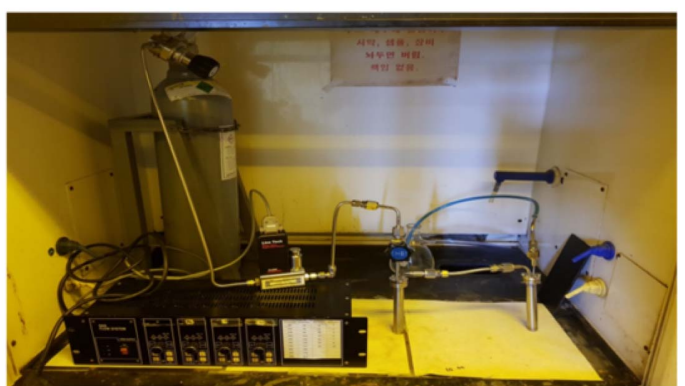

Figure 1. (a) Schematic diagram of $\mathrm{NO}$ oxidation and $\mathrm{NO}_{2}$ absorption system used in this work, and (b) images of the actual home-made system.

$$
2 \mathrm{NO}_{2}+\mathrm{NaOH} \rightleftarrows \mathrm{NaNO}_{2}+\mathrm{HNO}_{3}
$$

\section{Experimental set-up and materials}

The $\mathrm{NO}_{\mathrm{x}}$ used in this experiment was simulated using $3 \% \mathrm{NO}+97 \% \mathrm{He}$ gas mixture in consideration of the health of the experimenter and the laboratory environment. Sodium chlorite $\left(\mathrm{NaClO}_{2}\right)$, which is an oxidizing agent for NO oxidation, was used by diluting the powder with water to a concentration, and further added hydrochloric acid $(\mathrm{HCl})$ was dissolved appropriately in accordance with $\mathrm{pH}$. For adsorption reaction of $\mathrm{NO}_{2}$, sodium hydroxide $(\mathrm{NaOH})$ was diluted with $40 \sim 60 \%$ aqueous solution. The supply of the simulated gas was maintained by MFC (Mass Flow Controller) and the range of $\mathrm{NO}$ gas flow rates were kept from 5 to $100 \mathrm{sccm}$. Figure 1(a) shows the schematic diagram of experimental setup used in this experiment. Figure 1(b) shows the actual home-made system. 3\% NO+ $97 \% \mathrm{He}$ gas mixture container, MFC \& controller, NO oxidation chamber and $\mathrm{NO}_{2}$ adsorption chamber can be seen from left side respectively.

\section{Experimental method}

Experiments were carried out by oxidizing $\mathrm{NO}$ to $\mathrm{NO}_{2}$ and absorbing $\mathrm{NO}_{2}$ as shown in Section 2.3., respectively. The aim of this study is to present the optimal $\mathrm{NO}_{\mathrm{x}}$ treatment method by examining the change of NO oxidation reaction depending on oxidant concentration $(1 \sim 10 \mathrm{M})$ change and oxidant $\mathrm{pH}(\mathrm{pH}=1 \sim 5)$ change, which could control by adding $\mathrm{HCl}$ into $\mathrm{NaClO}_{2}$. In addition, we tried to suggest a method to improve $\mathrm{NO}_{2}$ absorption by conducting $\mathrm{NO}_{2}$ reduction reaction with reducing agent $(\mathrm{NaOH})$ concentration $(40 \sim 60 \%)$. For second step $\mathrm{NO}_{2}$ reduction reaction, $\mathrm{NO}$ gas was also supplied (see reaction 3). 


\section{Results and Discussion}

Figure 2(a) shows the changes of $\mathrm{NO}_{2} / \mathrm{NO}$ conversion ratio according to the concentration of oxidant $\left(\mathrm{NaClO}_{2}\right)$. As the concentration of $\mathrm{NaClO}_{2}$ increases under $100 \mathrm{sccm}$ of the $\mathrm{NO}$ gas flow rate, $\mathrm{NO}$ is more oxidized to $\mathrm{NO}_{2}$. It is shown that $\mathrm{NO}$ oxidation can occur only when $\mathrm{NaClO}_{2}$ concentration is more than $1 \mathrm{M}$. Figure 2(b) shows that under $10 \mathrm{M}$ of the $\mathrm{NaClO}_{2}$ concentration, the $\mathrm{NO}$ oxidation reaction occurs linearly with increasing $\mathrm{NO}$ gas flow rate, and the NO oxidation reaction can occur only when the NO gas flow rate is at least $5 \mathrm{sccm}$. Therefore, figures 2 (a) and (b) show that $\mathrm{NO}_{2} / \mathrm{NO}$ conversion ratio of $20 \%$ can be obtained when the $\mathrm{NaClO}_{2}$ concentration is $10 \mathrm{M}$ and the $\mathrm{NO}$ gas flow rate is $100 \mathrm{sccm}$, respectively. However, this is much less efficient than selective non-catalytic reduction $(50 \sim 60 \%)$. Since the wet reaction depends on various parameters (type of oxidizer and reducing agent, concentration, $\mathrm{pH}$, reaction temperature, absorption method and titration method), therefore, we think that the removal efficiency can be greatly improved by adjusting the above variables well. This means that it is still necessary to develop a new concept adsorbent capable of adsorbing / removing the ultrafine dust which does not have the technology to completely remove the ultrafine dust.

As shown in Section 2.3, the formation of chlorine dioxide $\left(\mathrm{ClO}_{2}\right)$ gas, which can generate in the acidic range below pH 5 and control by adding $\mathrm{HCl}$ into $\mathrm{NaClO}_{2}$, is
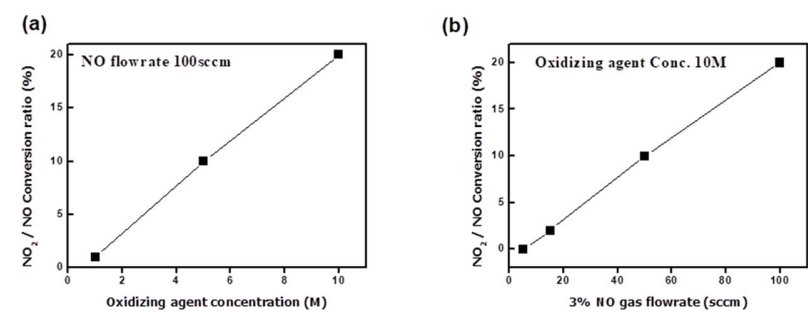

Figure 2. (a) The change of $\mathrm{NO}_{2} / \mathrm{NO}$ conversion ratio according to the concentration of oxidizing agent, and (b) the change of $\mathrm{NO}_{2} / \mathrm{NO}$ conversion ratio according to the $\mathrm{NO}$ gas flow rate at $10 \mathrm{M}$ of oxidizing agent.

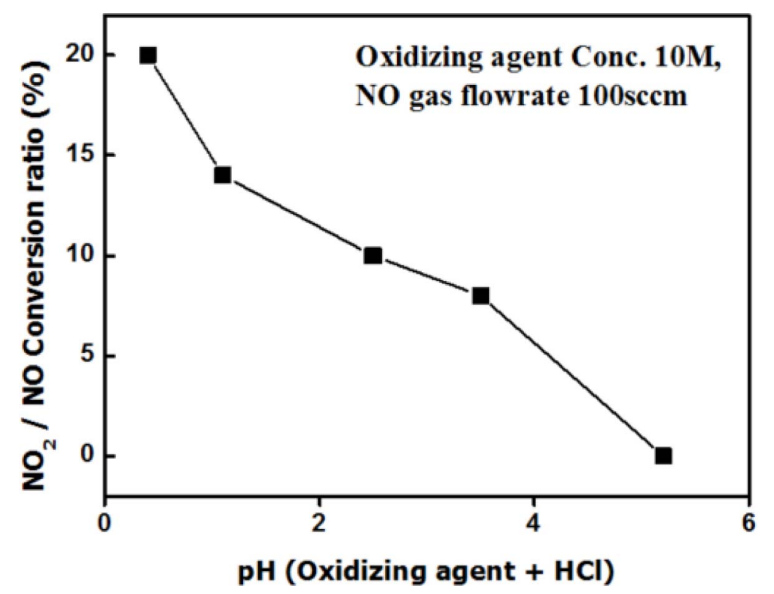

Figure 3. $\mathrm{NO}_{2} / \mathrm{NO}$ conversion ratio vs. $\mathrm{pH}$ change. very important for the reaction of $\mathrm{NO}$ oxidation. Figure 3 shows that $\mathrm{NO}$ is effectively oxidized to $\mathrm{NO}_{2}$ as the $\mathrm{pH}$ of the oxidizing agent decreases with hydrochloric acid added to the oxidizing agent $\left(\mathrm{NaClO}_{2}\right)$. Also, when the $\mathrm{pH}$ is above 5 , the NO oxidation reaction hardly occurs. This means that the lower the $\mathrm{pH}$ of the oxidant under the optimal conditions (i.e. $\mathrm{NaClO}_{2}$ concentration: $10 \mathrm{M}$ and NO gas flow rate: $100 \mathrm{sccm}$ ) as shown in figure 2, the more $\mathrm{ClO}_{2}$ is generated and the $\mathrm{NO}$ oxidation reaction is further promoted.

Figure 4(a) shows that the higher the $\mathrm{NaOH}$ concentration, the more the $\mathrm{NO}_{2}$ absorption (reduction) reaction occurs, and figure 4(b) shows that the $\mathrm{pH}$ of $\mathrm{NaOH}$, the $\mathrm{NO}_{2}$ absorbent, continues to decrease as the $\mathrm{NaOH}$ concentration increases. This means that the $\mathrm{pH}$ of the $\mathrm{NaOH}$ is reduced because the nitric acid $\left(\mathrm{HNO}_{3}\right)$ resulting from the $\mathrm{NO}_{2}$ reduction reaction (see reaction (8) in Section 2.3) causes the neutralization reaction with $\mathrm{NaOH}$ to produce water continuously. Therefore, it is possible to determine the concentration of $\mathrm{HNO}_{3}$ produced as a result of the $\mathrm{NO}_{2}$ absorption reaction if the exact concentration is obtained by titrating with the standard acid solution $(\mathrm{HCl})$ after accurately measuring the volume of the absorbent $(\mathrm{NaOH})$ remaining after the reaction, and further, $\mathrm{NO}_{2} / \mathrm{NO}$ conversion ratio was obtained. Based on these results, it was found that the removal efficiency of NO gas was up to $20 \%$ in this study.

Figure 5(a), similar to figure 4(b), shows that the $\mathrm{pH}$ of the absorbent $\mathrm{NaOH}$ decreases gradually as the concentration of oxidizing agent $\left(\mathrm{NaClO}_{2}\right)$ increases. Figure 5(b) also shows that the concentration of nitric acid $\left(\mathrm{HNO}_{3}\right)$ increases continuously as the concentration increases. This means that the NO removal efficiency is rather low, but it is a method that can easily remove NO gas with a relatively
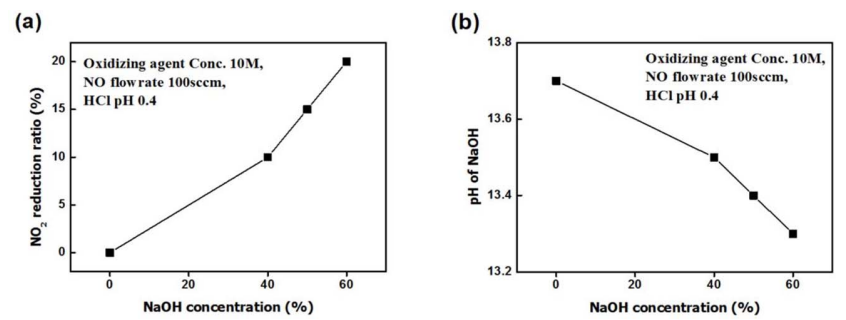

Figure 4. Changes of (a) $\mathrm{NO}_{2}$ reduction ratio and (b) $\mathrm{pH}$ of $\mathrm{NaOH}$ with the $\mathrm{NaOH}$ concentrations. (a)

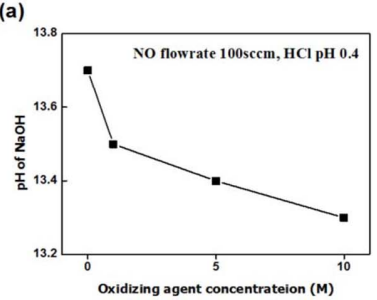

(b)

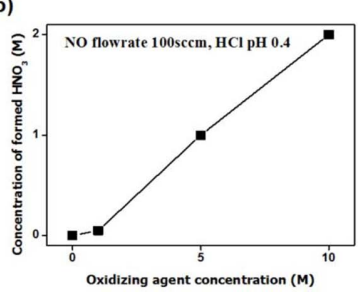

Figure 5. Changes of (a) $\mathrm{pH}$ of $\mathrm{NaOH}$ and (b) concentration of formed $\mathrm{HNO}_{3}$ according to the concentrations of oxidizing agent. 
simple device without existing large-scale expensive equipment. Therefore, our newly developed method can be applied to the capture and removal of ultrafine dust caused by air pollution in the future.

\section{Conclusions}

It was found that NO removal efficiency increased as the concentration of oxidant increased (as the flow rate of $\mathrm{NO}$ gas increased by more than $100 \mathrm{sccm}$ ), and NO decreased more effectively as the $\mathrm{pH}$ of hydrochloric acid added to the oxidant was lower. The $\mathrm{NO}_{2}$ uptake was better with increasing $\mathrm{NaOH}$ concentration, but the molar concentration (M) was more important than the $\mathrm{NaOH}$ concentration of $40 \%$ or more. It was found that the NO removal efficiency was $\sim 20 \%$ lower than that of the selective NO reduction, suggesting that if we could precisely control the variable parameters of influencing the NO removal efficiency, more higher NO removal efficiency (possibly over $40 \%$ ) than now would get. Indeed, this experimental method is expected to be a new method that can be applied to the capture and removal of ultrafine dust caused by air pollution because it is a method that can easily remove NO gas by a simple device without expensive giant equipment.

\section{Acknowledgements}

This work was partially supported by the CBDRC of the Sungkyunkwan University

\section{References}

[1] D. Kang and J.-E. Kim, J. Korean Med. Sci. 29, 621 (2014).

[2] H. Lee, J. Kim, C.-L. Myung, and S. Park, J. of Mechanical Science and Technology 23, 1591 (2009).

[3] A. G. Nord and K. Tronner, Water, Air and Soil Pollution 85, 2719 (1995).

[4] D. Harikishore, K. Reddy, and S.M. Lee, J. Environ. Anal. Toxicol. 2, 1 (2012)

[5] L. Bityukova, Water, Air, and Soil Pollution 172, 239 (2006).

[6] D.-S. Kim, J. Jeong, and J. Ahn, J. Korean Soc. Atmos. Environ. 32, 422 (2016).

[7] Sunita Bhargava and Sharad Bhargava, J. of Applied Chemistry 5, 19 (2013).

[8] İ. A. Reșitoğlu, K. Altinisik, and A. Keskin, Clean Technol. Environ. Policy 17, 15 (2015)

[9] UNCTAD, Review of Maritime Transport 2016, United Nations Publications (2016) pp. 1-104.

[10] A. Singh and M. Agrawal, J. of Environmental Biology 29, 15 (2008).

[11] D. Shimokuri, S. Fukuba, and S. Ishizuka, Proceedings of the Combustion Institute 35, 3573 (2015).

[12] J. Odgers and D. Kretschmer, The American Society of Mechanical Engineers 2, 1 (1985).

[13] D.W. Pershing and J. O. L. Wendt, Symposium (International) on Combustion 16, 389 (1977).

[14] S. Mahmoudi, J. Baeyesns and J. P.K. Seville, Biomass and Bioenergy 34, 1393 (2010).

[15] S. W. Bae, S. A. Roh, and S. D. Kim, Chemosphere 65, 170 (2006).

[16] X. Han, X. Wei, U. Schnell, and K. R.G. Hein, Combustion and Flame 132, 374 (2003).

[17] M. F. Irfan, J. H. Goo, and S. D. Kim, Applied Catalysis B: Environmental 78, 267 (2008).

[18] N.W. Cant and A. D. Cowan, Catalysis Letters 46, 207 (1997).

[19] H. W. Hsu, C. J. Lee, and K. S. Chou, Chem. Eng. Comm. 170, 67 (1997).

[20] C. Baukal, Metal Finishing 103, 18 (2005). 